\title{
Aplikované pohybové aktivity v mezinárodním kontextu
}

\section{Adapted Physical Activity: International perspectives}

\section{Martin Kudláček}

Katedra aplikovaných pohybových aktivit, Fakulta tělesné kultury, Univerzita Palackého, Olomouc, Česká republika

\section{Abstrakt:}

Aplikované pohybové aktivity jsou oborem činností zaměrených na poskytování služeb osobám se specifickými potřebami (mj. zdravotní postižení) a akademickou disciplínou, která podporuje přijímání jinakosti a propaguje poskytování služeb a integraci osob se zdravotním postižením. Aplikované pohybové aktivity zahrnuji mimo jiné tělesnou výchovu, sport, rekreaci a rehabilitaci osob se zdravotním postižením. Cílem tohoto př́spěvku je popsat základni historické a koncepční postavení APA v rámci kinantropologie v kontextu Evropy, světa i České republiky. $V$ rámci tohoto př́spěvku se zaměrime na následujici témata: (a) světová historie a vědecké společnosti IFAPA, EUFAPA a vybrané národni společnosti (př. PTN-AAF, SNAFA, ČAAPA, NCPERID), (b) vědecké konference a časopisy, (c) rámec kompetencí odborniků se zaměrením na aplikované pohybové aktivity s akcentem na projekty APENS a EUSAPA a (d) studijni obory v USA, EU a České republice.

\section{Abstract:}

Adapted physical activity is a profession focused on providing services to persons with special needs (also those with disabilities) and an academic discipline, which supports acceptance of differences and promo- 
tes services and inclusion of persons with disabilities. Adapted physical activity includes above all, physical education, sport, recreation and rehabilitation of persons with disabilities. The purpose of this presentation is to describe basic historical and conceptual position of APA in kinesiology in world, Europe and the Czech Republic. IN the presentation we will focus on following topics: (a) world history of scientific organization IFAPA, EUFAPA and selected national organizations (e. g. PTN-AAF, SNAFA, CAAPA, NCPERID), (b) scientific conferences and journals, (c) Framework of knowledge and competencies with the focus on APA (projects APENS and EUSAPA), and (d) study programs in the USA, EU and the Czech Republic.

Kličcová slova: ISAPA, EUCAPA, EUJAPA, APAQ, kompetence, standardy.

Key words: ISAPA, EUCAPA, EUJAPA, APAQ, competencies, standards.

\section{ÚVOD}

Termín aplikované pohybové aktivity je specificky českým termínem vycházejícím z anglického originálu ,,adapted physical activity“, který je ústředním tématem názvu mezinárodních organizací „International Federation of Adapted Physical Activity či European Federation of Adapted Physical Activity“. Český termín aplikované pohybové aktivity je výsledkem odborných aktivit prof. Válkové z počátku 90. let 20. století. Válková (2010) uvádí, že v České republice byla obecně přijata definice Válkové (1996, p. 2): „Aplikované pohybové aktivity reprezentují multidisciplinárni strukturovaný systém veškerých kontextů pohybových (i sportovnich) aktivit osob se specifickými potřebami, at' už v prostředi separovaném, paralelním či integrovaném, realizovaný v souladu se zájmy, schopnostmi či limity daných osob. V př́padech, kdy individuální limity jsou v podstatě neměnné a osobu vlastně přizpiosobit nelze, je potřeba změnit prostředí (environmentální přistup). I když APA vycházi z pojetí kategoriálního (respekt k obecným principům kontraindikací, 
pochopeni základních principů PA dané kategorie), v konkrétnich vztazich ke konkrétnímu jedinci je nutné modifikovat, adaptovat vnějši vlivy prostředí a následně je aplikovat, a to z vymezených hledisek: (a) komunikace, (b) metody, (c) obsahu činností, (d) pravidel, (e) podmínek, př́stupu, prostředi a pomůcek (asistence). "Tato definice je velmi podobná pojetí Evropské federace APA, která APA definuje jako obor činností zaměřených na poskytování služeb osobám se specifickými potřebami (mj. zdravotní postižení) a akademickou disciplínou, která podporuje přijímání jinakosti, prosazuje zlepšování přístupu k aktivnímu životnímu stylu a ke sportu a propaguje inovační a kooperační systémy poskytování služeb a zapojení a zmocnění osob se zdravotním postižením. Aplikované pohybové aktivity zahrnují mimo jiné tělesnou výchovu, sport, rekreaci a rehabilitaci osob se zdravotním postižením (EUFAPA, 2006).

\section{Terminologie a APA v USA}

Pozorný čtenář se základy anglického jazyka může namítnout, že termín ,aplikované“ se od termínu „,adapted“ liší. Slovo adapted bývá do českého jazyka překládáno většinou modifikované, přizpůsobené či adaptované. Slovník cizích slov (2001, p. 64) popisuje význam slovesa aplikovat takto: ,použivat, použit, využivat, využit, uplatňovat, uplatnit, popř. též s prizpưsobením něčeho $k$ nečemu“. Vidíme, že obě slova pracují s termínem přizpůsobení, který je také klíčovým pojmem v oblasti aplikovaných pohybových aktivit. Aplikované pohybové aktivity jsou relativně mladou disciplínou. V České republice se tento termín začíná používat od poloviny 90 . let 20 . století v souvislosti se studijním oborem Aplikovaná tělesná výchova na olomoucké Fakultě tělesné kultury. Toto studium odpovídá americkému studiu s názvem ,Adapted physical education“, které je v USA známo od poloviny 60. let 20. století, kdy došlo $\mathrm{k}$ přesunu akcentu ze zdravotní/léčebné TV na TV aplikovanou (adapted). Prvním autorem studijního textu s názvem „Adapted physical education“ byl v roce 1954 Arthur Daniels (Sherrill \& DePauw, 1997), který pracoval na významných univerzitách v USA (University of Illinois 1934-1942; Ohio State University 1945-1957; Indiana University 
od r. 1957). Prapůvodní kořeny APA můžeme datovat až kolem roku 3000 př. n. 1. (Kudláček, 2011; Sherrill, 2004). Starověcí Č́íňané věřili $\mathrm{v}$ důležitost zdravého těla a brzy vyvinuli cvičení, které prospívalo zdraví. Byly to vnitřní formy kung fu, tai chi a čchi kung. Většina učebnic aplikovaných pohybových aktivit (Seaman et al., 2003; Sherrill, 2004; Winnick, 2005) uvádí své kořeny v Evropě a vychází ze švédského tělesného cvičení zavedeného P. H. Lingem (1776-1839), který objevil blahodárný vliv cvičení, když mu pomohlo uzdravit jeho slabou paži. Tento systém se tak stal předchůdcem zdravotní tělesné výchovy a později aplikovaných pohybových aktivit.

Americký termín „Adapted Physical Education“ je nejčastěji užívaným termínem pro tuto disciplínu, profesi a poskytování služeb ve Spojených státech. Zahrnuje zejména př́mou výuku studentů se speciálními vzdělávacími potřebami (SVP) a poskytování podpory učitelům tělesné výchovy (Lytle and Hutchinson, 2004). Dalším, u nás méně známým, studijním oborem v USA je „Therapeutic recreation“, který se od ATV liší tím, že se zaměřuje na volnočasové pohybové aktivity osob se speciálními potřebami. Zastřešující této profese v USA je organizace American Therapeutic Recreation Association (http://www.atra-online.com) a organizace National Council for Therapeutic Recreation Certification, která se zaměřuje na certifikační programy v USA. Aplikovaná tělesná výchova je v USA spojena s organizací National Consortium for Physical Education and Recreation for Individuals with Disabilities (http://www.ncperid. org) a organizací Adapted Physical Activity Council, která je součástí aliance AAHPERD (American Alliance for Health, Physical Education, Recreation and Dance). Tyto organizace také společně propagují americký certifikační program APENS (Baloun \& Kudláček, 2012). V USA každoročně probíhají národní konference $\mathrm{v}$ těchto dvou oblastech, přičemž oblast ATV je součástí mnohatisícových kongresů aliance AAHPERD. Dle dostupných informací je v USA možné studovat TR i ATV na více než 60 univerzitách. Mezi tradiční a velmi známé programy patří programy, jejich profesoři jsou zároveň autory významných publikací a studijních materiálů např. Texas Womans University (Claudine Sher- 
rill, Ron Frech, Ron Davis, Jean Pyfer, Carol Huettig), University of Virginia (Martin Block, Luke Kelly), SUNY Brockport (Joseph Winnick, Lauren Lieberman, Cathy Houston-Wilson, Francis Kozub). Více informací $\mathrm{k}$ nabízeným programům můžete najít na následujících webových stránkách http://www.ncperid.org/directory.htm a http://www.recreation therapy.com/trcollg.htm.

Další významní představitelé severoamerické APA jsou zástupci kanadské APA, mezi které patří např́íklad Greg Reid (McGill University), Donna Goodwin (University of Alberta), Colin Higgs (Memorial University of Newfoundland). Ve srovnání s USA však oblast APA v Kanadě není rozvinutá ve vlastní profesi, ale je součástí profesní př́ípravy učitelů TV a pedagogů volného času. Přesto však právě v Kanadě můžeme najít dva následováníhodné př́klady z praxe $\mathrm{v}$ oblasti aplikovaných pohybových aktivit. Na již dříve zmíněné University of Alberta se nachází jedno z nejstarších Center APA na světě s názvem The Steadward Centre for Personal and Physical Achievement (http://www.steadwardcentre.ualberta.ca). Toto centrum usiluje o propojení: (a) nabídek kvalitních volnočasových pohybových aktivit pro osoby se zdravotním postižením, (b) VŠ vzdělávání studentů v oblasti TV a sportu a (c) výzkum v oblasti aplikovaných pohybových aktivit. Druhým př́ikladem je koncept systémové podpory sportu v Kanadě s názvem Long Term Athlete Development, který má také samostatnou část věnovanou podpoře sportu osob se zdravotním postižením s názvem No Accidental Champions (http://canadian sportforlife.ca/resources/no-accidental-champions-ltad-athletes-disability2nd-edition).

\section{Mezinárodní organizace a aktivity}

Francouzsky mluvící odborníci z Kanady a Belgie, kteří roku 1973 založili Mezinárodní federaci aplikovaných pohybových aktivit (Federation Internationale de l' Activite Physique Adaptee - International Federation of Adapted Physical Activity, IFAPA), měli širší vizi, která zahrnovala mnoho profesí, věkových skupin a poskytovaných služeb. Původním cílem IFAPA bylo ,poskytovat globální podporu odborníkům, 
kteří používají aplikované pohybové aktivity pro výuku, rekreaci, rehabilitaci a výzkum“. V 70. letech 20. století byly pojmy aplikovat (adapt) a aplikovaný (adapted) považovány za dobře srozumitelné ve francouzštině, angličtině a v dalších románských jazycích. Techniky pro aplikování (modifikaci) aktivit, výuky, programů a pomůcek byly popsány ve zdrojích pod nadpisy jako nápravná tělesná výchova, zdravotní tělesná výchova, aplikovaná tělesná výchova, sportovní terapie nebo sporty pro hendikepované. V zemích jako je Německo, Česká republika a Japonsko, jejichž jazyky byly odvozeny z jiných kořenů, byly aplikované strategie rovněž používány, přestože anglický termín ,adapted“ nebyl zcela srozumitelný (Hutzler \& Sherrill, 2007, p. 3).

Oblast aplikovaných pohybových aktivit na evropské úrovni podporuje zejména Evropská federace aplikovaných pohybových aktivit (European Federation of Adapted Physical Activity), jejíž počátky se datují do 80. let 20. století, kdy Dr. Jean-Claude DePotter uspořádal první evropský kongres na belgické Université Libre de Bruxelles s cílem založit evropskou pobočku mezinárodní federace (IFAPA). DePotter se poté také stal prezidentem IFAPA (1987-1991) a velice aktivně se podílel na vývoji př́slušných studijních programů (EMDAPA a DEUAPA). Evropskými předsedy Evropské asociace pro výzkum v oblasti aplikovaných pohybových aktivit (EARAPA) v následujících letech byli: Dr. Gudrun Doll-Tepper, Svobodná univerzita v Berlíně, Německo (19871993), Dr. Herman Van Coppenolle, K. U. Leuven, Belgie (1993-2002), Dr. Maria Dinold, Vídeňská univerzita, Rakousko (2002-2006), a Dr. Jean-Claude DePotter (2006-2010, nový název: Evropská federace aplikovaných pohybových aktivit - EUFAPA) a v současné době Dr. Martin Kudláček, Univerzita Palackého v Olomouci, Česká republika (Kudláček, 2011).

Mezinárodní federace IFAPA sdružuje převážně odborníky z akademických institucí, kteří bádají v oblasti APA a rozvíjejí ATV a APA $\mathrm{v}$ rámci univerzitních studijních programů. IFAPA organizuje pravidelné mezinárodní konference (ISAPA) již od roku 1977 a od roku 1984 vydává ve spolupráci s vydavatelstvím Human Kinetics čtvrtletník s ná- 
zvem Adapted Physical Activity Quarterly. Tento časopis je indexován mj. v databázích EBSCO, MEDLINE, SCOPUS a WOS (v roce 2011 IF $=1,48)$

Tab. 1: Historie mezinárodních konferencí ISAPA a EUCAPA

\begin{tabular}{|l|l|}
\hline Konference ISAPA & Konference EUCAPA \\
\hline 1977 Quebec, Kanada & 1986 Brusel, Belgie \\
1979 Brusel, Belgie & 1993 Leuven, Belgie \\
1981 New Orleans, USA & 1995 Leuven, Belgie \\
1983 Londýn, Velká Británie & 1998 Soluň, Řecko \\
1985 Toronto, Kanada & 2001 Vídeň, Rakousko \\
1987 Brisbane, Austrálie & 2002 Amiens, Francie \\
1989 Berlín, Německo & 2004 Dortmund, Německo \\
1991 Miami, USA & 2006 Olomouc, Česká republika \\
1993 Jokohama, Japonsko & 2008 Turín, Itálie \\
1995 Oslo, Norsko & 2010 Jyväskylä, Finsko \\
1997 Quebec, Kanada & 2012 Killarney, Irsko \\
1999 Lleida/Barcelona, Španělsko & 2014 Madrid, Španělsko \\
2001 Vídeň, Rakousko & \\
2003 Soul, Korea & \\
2005 Verona, Itálie & \\
2007 Rio Claro, Brazílie & \\
2009 Gävle, Švédsko & \\
2011 Paříž, Francie & \\
2013 Istanbul, Turecko & \\
\hline
\end{tabular}

Prezidenty IFAPA byly v minulosti významné osobnosti z akademického prostředí APA (obr. 1). Prvním prezidentem byl Clermont Simard z Kanady (1979-1987), následovaný Jean Claude De-Potterem z Belgie (1987-1991), Gudrun Doll Tepper z Německa (1991-1995), Karen De-Pauw z USA (1995-1999), Gregem Reidem z Kanady (1999- 
2003), Claudine Sherrill z USA (2003-2007), Shayke Hutzlerem z Izraele (2007-2011) a současnosti je prezidentkou IFAPA Claire Brouisiere z Francie.

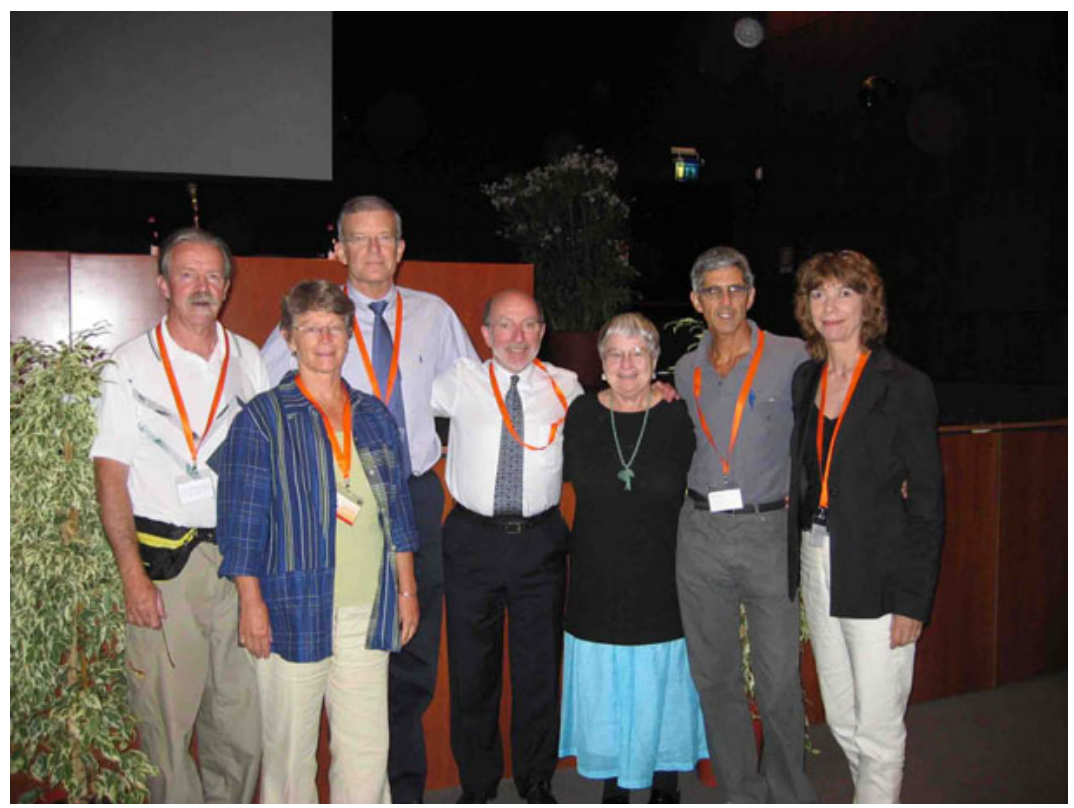

Obr 1: Bývalý prezidenti organizace IFAPA (pořadí zleva Clermont Simard, Karen De-Pauw, Greg Reid, Jean Claude De-Potter, Claudine Sherrill, Shayke Hutzler a Gudrun Doll Tepper)

IFAPA má také tři regionální členy: (a) North American Federation of APA - NAFAPA, (b) Asian Society of Adapted Physical Education ASAPE, a (c) European Federation of Adapted Physical Activity - EUFAPA.

EUFAPA je evropská organizace zabývající se propagací a šiřením zkušeností, výsledků a poznatků v oblasti aplikovaných pohybových ak- 
tivit a sportovní nauky a jejich praktickým využitím ve prospěch jedinců všech věkových kategorií. Hlavními cíli EUFAPA jsou: (a) podporovat evropskou spolupráci v oblasti pohybových aktivit ve prospěch jedinců s různými schopnostmi; (b) podporovat, stimulovat a koordinovat vědecký výzkum a zkušenosti v oblasti aplikovaných pohybových aktivit (APA) po celé Evropě a podporovat využití výsledků výzkumu v různých oblastech odborné praxe, jako je např. vzdělávání, adaptace, začlenění, trénování, sport ve volném čase, rekreační sport a rehabilitace; a (c) zpřistupňovat vědecké poznatky a praktické zkušenosti týkající se aplikovaných pohybových aktivit všem zainteresovaným národním a mezinárodním organizacím a institucím (www.eufapa.eu).

EUFAPA dále propaguje vědecká zjištění v oblasti APA v časopise European Journal of Adapted Physical Activity (EUJAPA) a odborných konferencích. European congresses (EUCAPA). EUJAPA je mezinárodní mezioborový časopis založený pro potřeby sdělování, sdílení a podporování akademického bádání zaměřeného na pohybové aktivity osob se speciálními potřebami. Články v časopise EUJAPA odrážejí mezioborovou povahu aplikovaných pohybových aktivit, od tělesné výchovy přes sport, rekreaci, rehabilitaci, tanec, až po sportovní medicínu nebo zdravotní péči. Tento mezioborový časopis přináší výsledky nejnovějšího akademického bádání v oblasti pohybových aktivit pro osoby se speciálními potřebami. EUFAPA zastřešuje také mezinárodní kongresy EUCAPA (European Congress of Adapted Physical Activity), které se konají pravidelně od roku 1986. V rámci evropského hnutí APA v některých zemích vznikají národní organizace APA. Tyto organizace můžeme rozdělit na tři kategorie: (a) profesní organizace (např. Francie nebo Rakousko), (b) vědecké organizace (Polsko) a (c) organizace, které spojují profesní i vědecké aspekty APA (např. Švédsko, Španělsko, Česká Republika).

Organizace, které se částečně vymykají profesně-akademickému pojetí aplikovaných pohybových aktivit, jsou mezinárodní sportovní organizace jako např́iklad Mezinárodní paralympijský výbor (IPC) nebo Mezinárodní hnutí speciálních olympiád (SOI). Obě organizace kladou 
důraz na vytváření kvalitních podmínek pro sportovce a propojení s akademickou obcí s cílem optimalizace sportovního tréninku a zdravého životního stylu sportovců se zdravotním postižením. SOI uspořádalo zajímavý projekt s názvem Special Olympics University Program, který se zaměroval na integraci témat SO do VŠ kurikul v oblasti TV a sportu. IPC má dva výbory, které jsou $\mathrm{z}$ našeho pohledu velmi zajímavě: (a) vědecký výbor a (b) vzdělávací výbor. Vědecký výbor koordinuje výzkumné aktivity na Paralympijských hrách a organizuje pravidelnou konferenci s názvem Vista. (V roce 2012 se konala již šestá konference v německém Bonnu, který je také sídlem IPC). Zajímavým projektem IPC je také IPC Academy (www.worldacademysport.com).

\section{Publikace v oblasti aplikovaných pohybových aktivit}

Odborné publikace tvoř́i významnou část každého studijního oboru, profese i akademické disciplíny. Vycházíme-li z literatury publikované v anglickém jazyce, mohli bychom ji rozdělit na: (a) odborné publikace $\mathrm{v}$ recenzovaných vědeckých časopisech, (b) odborné a populárně naučné časopisy, (c) studijní texty, (d) monografie, nebo (e) odborné texty dostupné na webových stránkách. Vlajkovou lodí mezi odbornými publikacemi v recenzovaných vědeckých časopisech je bezesporu časopis Adapted Physical Activity Quarterly vydávaný Human Kinetics již od roku 1984. Dalším významným časopisem je Therapeutic Recreation Journal, nově dostupný přes webové rozhraní (http://js.sagamorepub. com/trj/index). Nejmladším recenzovaným časopisem je oficiální časopis Evropské federace APA European Journal of Adapted Physical Activity dostupný přes webové rozhraní (http://www.eujapa.upol.cz). $\mathrm{V}$ angličtině nejznámějším odborným časopisem je americká Palaestra (http://www.palaestra.com) a dále časopisy jako Sports and Spokes (http://pvamag.com/sns/) vydávaný organizací paralyzovaných veteránů nebo Paralympian vydávaný IPC. Studijní materiály a učebnice jsou nedílnou součástí amerického vzdělávacího systému a jsou hojně rozšířené mj. v USA a Kanadě. Historicky prvním studijním textem byl v roce 1954 titul „Adapted physical education“ od Arthura Danielse (Sherrill \& DePauw, 1997). V dnešní době můžeme na trhu najít vel- 
ké množství obdobných studijních textů. Mezi nejvýznačnější patří níže uvedené publikace.

- Auxter, D., Pyfer, J., Zittel, L., Roth, K. \& Huettig, C. (2010). Principles and Methods of Adapted Physical Education and Recreation, (11 ${ }^{\text {th }}$ Ed.) Boston, MA: WCB/McGraw-Hill.

- Block, M. (2007). A teacher's guide to including students with disabilities in general physical education ( $4^{\text {th }}$ edition). Maryland: Paul H. Brooks Publishing Co.

- Goosey-Tolfrey, V. Ed. (2010). Wheelchair Sport: A complete guide for athletes, coaches, and teachers. Champaign, IL: Human Kinetics.

- Hodge, S., Lieberman, L. \& Murata, N. (2012). Esentials of Teaching Adapted Physical Education. Scottsdale, AZ: Holcomb Hathaway.

- Sherrill, C. (2004). Adapted physical activity, recreation and sport: Crossdisciplinary and lifespan $\left(6^{\text {th }}\right.$ ed.). Boston, MA: WCB/McGraw-Hill.

- Winnick, J. P. (2011). Adapted physical education and sport. ( $5^{\text {th }}$ ed.). Champaign, IL: Human Kinetics.

Velmi zajímavými, inspirativními a spolehlivými zdroji informací jsou také webové stránky National Center on Health, Physical Activity, and Disability (http://www.ncpad.org), the Inclusion Club (http://theinclusionclub.com/), nebo webové stránky IPC či SOI.

\section{Příklady dobré praxe}

Příkladů dobré praxe v Evropě i ve světě jsou stovky. Některé z nich je možné najít na webových stránkách www.eufapa.eu nebo www.eusapa.eu, další najdete v různých časopisech a studijních textech. Pro potřeby tohoto prríspěvku jsou použity tři příklady z různých oblastí APA v Evropě: (a) vědecko-výzkumná, (b) profesní a (c) vysokoškolská. Peter Harrison Centre for Disability Sport je součástí Loughborough University (Velká Británie) a zaměřuje se na tři oblasti: (i) psychosociální zdraví a pohoda osob se zdravotním postižením, (ii) optimalizace výkonu a (iii) zdraví sportovců. Toto centrum intenzivně spolupracuje s britským i mezinárodním paralympijským výborem a patři mezi nej- 
lepší centra na světě svého druhu. Cara Adapted Physical Activity Center v Irsku je součástí Institute of Technology v irském městě Tralee (http://www.caraapacentre.ie). Toto centrum koordinuje rozvoj APA v Irsku v rámci projektu SIDO (Sport Inclusion Disability Officers), v rámci studijních programů na ITT, celoživotního vzdělávání učitelů, pedagogických pracovníků a trenérů i v rámci organizování volnočasových pohybových aktivit osob se zdravotním postižením. European University Diploma in Adapted Physical Activity (EUDAPA) je specializačním modulem s dotací 60 ECTS, která je konstruována jako 30 kreditový modul APA ve finském Vierumakki Haaga-Helia University of Applied Sciences) na bázi spolupráce v rámci programuErasmus. Českou republiku v tomto modulu reprezentují prof. Hana Válková, doc. Martin Kudláček a dr. Zbyněk Janečka z Fakulty tělesné kultury Univerzity palackého v Olomouci. Tomuto modulu předchází 10 kreditů na domácí univerzitě a po absolvování semestru ve Finsku ještě 20 kreditů praxe opět na domácí univerzitě.

\section{ZÁVĚR}

Pokud se ohlédneme za historií aplikovaných pohybových aktivit, můžeme najít kořeny až ve staré Číně či švédském systému léčebné gymnastiky. Historie APA resp. aplikované tělesné výchovy, jak ji v současnosti vnímáme v ČR nebo v USA, se datuje do 50. let 20. století. Není tedy žádným benjamínkem a má velmi bohatou a zajímavou historii a současné př́iklady z akademické i profesní oblasti. V ČR můžeme počátky studijního oboru s názvem aplikované tělesné výchovy najít začátkem 90. let v práci profesorky Hany Válkové v Olomouci. V posledních pěti letech se zdá, že tato oblast expanduje a zvyšuje svou kvalitu. Jsme svědky vzniku studijních materiálů, studijních programů a předmětů, odborných časopisů, konferencí a profesní organizace Česká asociace aplikovaných pohybových aktivit. V praxi vidíme rostoucí počty programů ve školách, rehabilitačních ústavech i sportovních centrech. Tento příspěvek by měl sloužit jako inspirace těm, kteří se snaží o budování a propagaci kvalitní APA v ČR, protože je známé, že kvalitní věci a příklady je dobré zkopírovat, nebo se jimi alespoň nechat inspirovat. 


\section{LITERATURA}

Auxter, D., Pyfer, J., Zittel, L., Roth, K. \& Huettig, C. (2010). Principles and Methods of Adapted Physical Education and Recreation, (11 ${ }^{\text {th }}$ ed.) Boston, MA: WCB/McGraw-Hill.

Baloun, L. \& Kudláček, M. (2012). Deskripce amerických standardů z oblasti aplikované tělesné výchovy. Aplikované pohybové aktivity $v$ teorii a praxi, 3 (2), 51-65.

Block, M. (2007). A teacher's guide to including students with disabilities in general physical education ( $4^{\text {th }}$ ed.). Maryland: Paul H. Brooks Publishing Co.

Goosey-Tolfrey, V. Ed. (2010). Wheelchair Sport: A complete guide for athletes, coaches, and teachers. Champaign, IL: Human Kinetics.

Hodge, S., Lieberman, L. \& Murata, N. (2012). Esentials of Teaching Adapted Physical Education. Scottsdale, AZ: Holcomb Hathaway.

Hutzler and Sherrill. (2007). Defining Adapted Physical Activity International Perspectives. Adapted Physical Activity Quarterly, 24, 1-20.

Kudláček, M. (2011). Aplikované pohybové aktivity v evropském kontextu. Tělesná kultura, 34 (2), 9-19.

Lytle, R. K., \& Hutchinson, G. E. (2004). Adapted physical educators: The multiple roles ofconsultants. Adapted Physical Aktivity Quarter$l y, 21,34-49$.

Seaman, J., DePauw, K. P., Morton, K., \& Omoto, K. (2003). Making connections: From theory to practice in adapted physical education. Scottsdale, AZ: Holcomb Hathaway.

Sherrill, C. (2004). Adapted physical activity, recreation and sport: Crossdisciplinary and lifespan $\left(6^{\text {th }}\right.$ ed. $)$. Boston, MA: WCB/McGraw-Hill. Sherrill, C., \& DePauw, K. P. (1997). Adapted physical activity and education. In J. D. Massengale \& R. A. Swanson, (Eds.), The history of exercise and sport science (pp. 39-108). Champaign, IL: Human Kinetics.

Válková, H. (2010). Teoretické vymezení APA jako kinantropologické disciplíny: Co to je, když se řekne APA? Aplikované pohybové aktivity $v$ teorii a praxi, 1 (1), 25-32. 
Winnick, J. P. (2005). Adapted physical education and sport. Champaign, IL: Human kinetics.

Winnick, J. P. (2011). Adapted physical education and sport ( $5^{\text {th }}$ ed.). Champaign, IL: Human Kinetics.

\section{KONTAKT:}

doc. Mgr. Martin, Kudláček, Ph.D., martin.kudlacek@upol.cz 